\title{
Occurrence of beetles (Insecta: Coleoptera) in mosquito ovitraps (Diptera: Culicidae, Culicinae) in an Atlantic Forest fragment
}

\author{
Emili Bortolon dos Santos ${ }^{1 *}$, Pedro Giovâni da Silva², Mario Arthur Favretto ${ }^{3}$ \& Gerson Azulim Müller
}

Programa de Pós-graduação em Entomologia, Universidade Federal do Paraná, Jardim das Américas, CEP 81531980, Curitiba - PR, Brazil

${ }^{2}$ Programa de Pós-graduação em Ecologia, Universidade Federal de Santa Catarina, CEP 88040-900, Florianópolis SC, Brazil

${ }^{3}$ Programa de Pós-graduação em Ecologia e Conservação, Universidade Federal do Paraná, Jardim das Américas, CEP 81531-980, Curitiba-PR, Brazil

${ }^{4}$ Instituto Federal de Ciência, Educação e Tecnologia Farroupilha, Rua Erechim, Planalto, CEP 98280-000, Panambi $-R S$, Brazil

*Corresponding author:emili.bsantos@gmail.com

\begin{abstract}
Ovitraps are generally used to collect immatures of Culicinae (Diptera: Culicidae). This study reports eight species of beetles found in ovitraps placed in an Atlantic Forest fragment in the state of Rio Grande do Sul, Southern Brazil. Seven species were classified in the family Scarabaeidae (subfamily Scarabaeinae), and one species in the family Hybosoridae (subfamily Hybosorinae). The first record of Canthon angularis Harold, 1868 in Rio Grande do Sul state is also documented.
\end{abstract}

Keywords: Detritivorous beetles, Hybosorinae, Scarabaeinae, Trap.

Resumo. Ocorrência de besouros (Insecta: Coleoptera) em ovitrampas de mosquitos (Diptera: Culicidae, Culicinae) em um fragmento da Mata Atlântica. Ovitrampas são geralmente usadas para coletar imaturos de Culicidae (Diptera). No entanto, este estudo reporta oito espécies de besouros encontrados em ovitrampas dispostas em um fragmento floresta de Mata Atlântica no estado do Rio Grande do Sul, sul do Brasil. Sete espécies foram classificadas na família Scarabaeidae (subfamília Scarabaeinae) e uma espécie na família Hybosoridae (subfamília Hybosorinae). O primeiro registro de Canthon angularis Harold, 1868 no estado do Rio Grande do Sul é também documentado.

Palavras-chave: Besouros detritívoros, Hybosorinae, Scarabaeinae, Armadilha.

Scarabaeinae and Hybosorinae are taxa (OCAMPO, 2006; SIMMONS \& RIDSDILL-SMITH, 2011). of detritivorous beetles that feed on decomposing These insects play important ecological roles organic matter, such as mammal excrements, (DAVIS, 2004; NicHols et al., 2008), and have been animal carcasses, and rotten plant material used as bioindicators of environmental quality in 
multiple ecosystems (DAVIS, 2004; AUDINo et al., 2014; VIEGAS et al., 2014). There are several kinds of traps used to collect these insects, such as light, (e.g. RONQUI \& LOPES, 2006), pitfall (e.g. SILVA et al., 2007), and flight intercept traps (e.g. CosTA et al., 2009). Pitfalls are buried in the soil and may be used with attractive baits, like flesh, decomposing fruits, or vertebrate excrement (SCHIFFLER et al., 2003; SPECTOR, 2006; AUdINo et al., 2011; SiLvA et al., 2011).

Some species of mosquitoes play an important role in the transmission of infectious agents to humans. A few specialized traps are used to capture adult mosquitoes and measure the density of the female population that is potentially infected. Ovitraps are an example of device used to capture mosquito eggs, which enable the measurement of bite rate of these dipterans (MARQUES et al., 1993). Ovitraps can be installed in urban or rural areas to monitor populations of Aedes aegypti (Linnaeus, 1762) and Haemagogus species, respectively. Gravid females are attracted to oviposit in those traps by chemicals released from the decomposition of grass in the water (TIKASINGH \& LAURENT, 1981; FANTINATTI et al., 2007). In this context, this study aimed to report the occurrence of adult beetles in ovitraps installed in an Atlantic Forest fragment in Southern Brazil and also discuss some aspects of the occurrence of this fact.

The study was developed in a forest fragment located in a rural area in the municipality

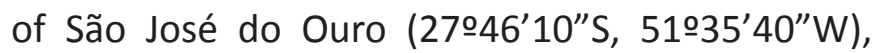
located in the northern region of Rio Grande do Sul State, $318 \mathrm{~km}$ from the capital Porto Alegre, Brazil. The area is composed by Araucaria forest (SONEGO et al., 2007) with a size of about 80 ha, altitude of
$823 \mathrm{~m}$, and subtropical climate.

A total of eight ovitraps were installed with the aim to capture mosquitoes eggs and larvae. They consisted of a brown plastic container, with a capacity of one liter $(20 \times 15 \mathrm{~cm})$, and were modified from TIKASINGH \& LAURENT (1981). Four traps were installed at ground level on the soil (not buried) and the other four were installed 15 $\mathrm{m}$ above the ground, arranged on tree branches, to check the mosquitoes site preference of oviposition. Two traps were installed at the edge of the forest fragment, four traps in the forest interior and two traps in a glade located near a puddle in the forest interior, and were verified every 15 days from October $6^{\text {th }} 2013$ to December $13^{\text {th }} 2013$.

In the traps, decomposing plant material was added to dechlorinate water, the former composed of dead leaves from leaf litter in a proportion of 4:1 (water: leaves), this water was changed every 15 days. Later on, insects captured were put in ethanol $70 \%$ and carried to the laboratory for identification. The beetle specimens were identified using dichotomous keys provided by OCAMPo (2006) and VAZ-DE-MELLo et al. (2011), and by comparison with specimens from the Entomological Collection of the Centro de Ciências Biológicas from Universidade Federal de Santa Catarina, where they were deposited.

Seven species of Scarabaeinae were found in the ovitraps of mosquitoes: Canthon angularis Harold, 1868: two males; Coprophanaeus saphirinus (Sturm, 1826): one female; Deltochilum brasiliense (Castelnau, 1840): one female; Deltochilum rubripenne (Gory, 1831) one male; Dichotomius assifer (Eschscholtz, 1822): one 
female and one male; Eurysternus francinae Génier, 2009: one female and one male; and Onthophagus tristis Harold, 1873: one female. One species of Hybosoridae, Coilodes aff. gibbus (Perty, 1930), two males, was also collected. Despite the considerable number of beetles that fall in the traps, only two exemplars were collected per species. All specimens were collected in the traps installed on the soil in the forest interior, because of ecological requirements of these Coleoptera species and because de forest edge was near a crop area, it is possible that the use of pesticides difficult the surviving of these beetles out of the forest. This was the first time that these beetles' taxa were recorded in ovitraps of mosquitoes.

Deltochilum brasiliense and $D$. rubripenne are roller species that builds spheres of food that are rolled and buried in the ground far away from the resource (HALFFTER \& EDMONDS, 1982); they has generalist feeding habit (ALMEIDA \& LOUZADA, 2009; SILVA et al., 2012). Canthon angularis is also a roller species, and is attracted to human excrement (MARTínez, 1959; CuLot et al., 2013). These species are associated with preserved Atlantic Forest areas from South-Central region of Neotropical region (ALMEIDA \& LOUZADA, 2009; SILVA et al., 2012; 2013).

\section{Dichotomius assifer and Onthophagus} tristis are tunneler species that buries food resources below or next to the feeding source (HANSKI \& CAMBEFORT, 1991). They have coprophagous feeding habit (SILVA et al., 2012; CAMPOS \& HERNÁNDEZ, 2013). Dichotomius assifer is also attracted to rotten flesh and decomposing fruits (SILVA et al., 2012). They are very common in Atlantic Forest areas in the Southern and Southeast Brazil (SILVA et al., 2011; SILVA et al.,
2013). Coprophanaeus saphirinus is also a tunneler species with necrophagous feeding habit (ALMEIDA \& LoUZADA, 2009; SILVA et al., 2012), also attracted by mammals excrements and decomposing fruits (SILVA et al., 2012). It occurs in Atlantic Forest from the Southern and Southeast regions of Brazil and also in Bahia (Brazil), Argentina and Paraguay (SILVA et al., 2011).

Eurysternus francinae is a dweller and coprophagous species that feeds and nests inside the resource (HALFFTER \& EDMONDS, 1982; CAMPOS \& HERNÁNDEZ, 2013). It occurs in the Atlantic Forest of Southeast Brazil (GÉNIER, 2009). The hybosorid $C$. aff. gibbus feeds mainly on excrement and rotten flesh in its adult stage. A lot of Hybosoridae species are attracted to light, and larvae have been collected from decomposing plant material, associated with roots (OCAMPO, 2006).

Most of the collected species were likely attracted to the ovitraps due to their detritivorous feeding habit. Twenty-one days after placing the traps, the water content showed a strong fetid odor (E. B. Santos, personal observation), which probably attracted the insects as they searched for food by smell (SIMMONS \& RIDSDILL-SMITH, 2011). Dung beetles have two foraging strategies in search for food: some species do cruising flights and others just perching on leaves waiting for the odor plume (GILL, 1991). There is a wide range of volatile compounds present in different rotting resources that can attract dung beetles (PFROMMER \& KRELL, 2004). When they found an odor plume dung beetles usually fly on or land near it. The fetid odor of rotting plant material and the landing on the food resources may explain the occurrence of different species of detritivorous beetles in the 
ovitraps. The biology of hybosorid beetles is not well known, but based on the results reported here there is a great chance that the species follow the same pattern described by dung beetles: flying on the resource attracted by the strong smell of rotting plant material.

One remarkable finding was the collection of $C$. angularis, a species reported for the first time in the state of Rio Grande do Sul, previously known to occur in the Brazilian states of Minas Gerais, Paraná, Rio de Janeiro, Santa Catarina and São Paulo, as well as Argentina and Paraguay. Moreover, it was possible to observe that beetles were attracted to decomposing plant material (leaf litter), a fact that, although reported in the literature, is less often observed, because most of the studies use excrement, carrion and fruits to attract this fauna. Therefore, the use of a highstage decomposed leaf litter, together with other collecting baits can contribute to a better sampling of these insects and also to the knowledge of their trophic preference. This is an important question to be elucidated about the biology of these insects.

\section{REFERENCES}

ALMEIDA, S.S.P. \& LouZADA, J.N.C. 2009. Estrutura da comunidade de Scarabaeinae (Scarabaeidae: Coleoptera) em fitofisionomias do Cerrado e sua importância para a conservação. Neotropical Entomology 38 (1): 32-43.

AUdino, L.D.; LOUZADA, J. \& COMITA, L. 2014. Dung beetles as indicators of tropical forest restoration success: Is it possible to recover species and functional diversity? Biological Conservation 169: 248-257.
Audino, L.D.; Silva, P.G.; NogueIRA, J.M.; Moraes, L.P. \& VAZ-DE-MELLO, F.Z. 2011. Scarabaeinae (Coleoptera, Scarabaeidae) de um bosque de eucalipto introduzido em uma região originalmente campestre. Iheringia, Série Zoologia 101 (1-2): 121-126.

CAMPOS, R.C. \& HeRnándeZ, M.I.M. 2013. Dung beetle assemblages (Coleoptera, Scarabaeinae) in Atlantic forest fragments in southern Brazil. Revista Brasileira de Entomologia 57 (1): 47-54.

Costa, C.M.Q.; SILVA, F.A.B.; FARIAS, A.I. \& MourA, R.C. 2009. Diversidade de Scarabaeinae (Coleoptera, Scarabaeidae) coletados com armadilhas de interceptação de vôo no Refúgio Ecológico Charles Darwin, IgarassuPE, Brasil. Revista Brasileira de Entomologia 53 (1): 88-94.

Culot, L.; Bovy, E.; Vaz-de-Mello, F.Z.; Guevara, R. \& GAlETTI, M. 2013. Selective defaunation affects dung beetle communities in continuous Atlantic rainforest. Biological Conservation 163: 79-89.

DAVIS, A.J. 2004. Species richness of dungfeeding beetles (Coleoptera: Aphodiidae, Scarabaeidae, Hybosoridae) in tropical rainforest at Danum Valley, Sabah, Malaysia. The Coleopterists Bulletin 54 (2): 221-231.

Fantinatti, E.C.S.; Duque, J.E.L.; Silva, A.M. \& NAVArro-Silva, M.A. 2007. Abundância e agregação de ovos de Aedes aegypti L. e Aedes albopictus (Skuse) (Diptera: Culicidae) no norte e noroeste do Paraná. Neotropical 
Entomology 36 (6): 960-965.

GÉNIER, F. 2009. Le genre Eurysternus Dalman, 1824 (Scarabaeidae: Scarabaeinae: Oniticellini), revision taxonomique et clés de determination illustrées. Sofia, Pensoft. 430 p.

GILL, B.D. 1991. Dung beetle in Tropical American Forest, pp. 211-229. In: HANSKI, I. \& CAMBEFORT, Y. (ed.) Dung beetle ecology. Princeton, Princeton University Press. 481 p.

HALFFTER, G. \& EDMONDS, W.D. 1982. The nesting behavior of dung beetles (Scarabaeinae): An ecologic and evolutive approach. México, Man and Biosphere Program UNESCO. 177p.

HANSKI, I. \& CAMBEFORT, Y. 1991. Competition in dung beetles, pp. 305-329. In: HASNKI, I. \& CAMBEFORT, Y. (ed.) Dung beetle ecology. Princeton, Princeton University Press. 481p.

Marques, C.C.A.; Marques, G.R.A.M.; Brito, M.; SANTOS-NETO, L.G.; ISHIBASHI, V.C. \& GOMES, F.A. 1993. Estudo comparativo de eficácia de larvitrampas e ovitrampas para vigilância de vetores de dengue e febre amarela. Revista de Saúde Pública 27 (4): 237-241.

Martínez, A. 1959. Catalogo de los Scarabaeidae Argentinos (Coleoptera). Revista del Museo Argentino de Ciencias Naturales Bernardino Rivadavia 5 (1): 1-126.

Nichols, E.; SPeCtOR, S.; LOUZAdA, J.; LARSEN, T.; AMÉzQUitA, S. \& FAVILA, M.E. 2008. Ecological functions and ecosystem services provided by Scarabaeinae dung beetles. Biological Conservation 141: 1461-1474.

OCAMPO, F.C. 2006. Phylogenetic analysis of the scarab Family Hybosoridae and monographic revision of the New World subfamily Anaidinae. 3. Phylogenetic analysis of the subfamily Anaidinae. Bulletin of the University of Nebraska State Museum 19: 13-177.

Pfrommer, A. \& Krell, F.T. 2004. Who steals the eggs? Coprophanaeus telamon (Erichson) buries decomposing eggs in western Amazonian rain forest (Coleoptera: Scarabaeidae). The Coleopterists Bulletin 58 (1): 21-27.

RonQUI, D.C. \& LOPES, J. 2006. Composição e diversidade de Scarabaeoidea (Coleoptera) atraídos por armadilha de luz em área rural no norte do Paraná, Brasil. Iheringia, Série Zoologia 96: 103-108.

SChIffler, G.; VAZ-De-Mello, F.Z. \& AzeVedo, C.O. 2003. Scarabaeidae s.str. (Coleoptera) do Delta do Rio Doce e Vale do Suruaca no município de Linhares, Estado do Espírito Santo, Brasil. Revista Brasileira de Zoociências 5 (2): 205211.

Silva, F.A.B.; Hernández, M.I.M.; IDE, S. \& MourA, R.C. 2007. Comunidade de escarabeíneos (Coleoptera, Scarabaeidae) copronecrófagos da região de Brejo Novo, Caruaru, Pernambuco, Brasil. Revista Brasileira de Entomologia 51 (2): 228-233.

SILVA, P.G. \& DI MARE, R.A. 2012. Escarabeíneos 
copro-necrófagos (Coleoptera, Scarabaeidae, Scarabaeinae) de fragmentos de Mata Atlântica em Silveira Martins, Rio Grande do Sul, Brasil. Iheringia, Série Zoologia 102 (2): 197-205.

Silva, P.G.; Vaz-de-Mello, F.Z. \& Di Mare, R.A. 2011. Guia de identificação das espécies de Scarabaeinae (Coleoptera: Scarabaeidae) do município de Santa Maria, Rio Grande do Sul, Brasil. Biota Neotropica 11 (4): 329-345.

Silva, P.G.; Vaz-de-Mello, F.Z. \& Di Mare, R.A. 2012. Attractiveness of different bait to the Scarabaeinae (Coleoptera: Scarabaeidae) in forest fragments in extreme southern Brazil. Zoological Studies 51 (4): 429-441.

SILVA, P.G.; VAZ-DE-MELLo, F.Z. \& DI MARE, R.A. 2013. Diversity and seasonality of Scarabaeinae (Coleoptera: Scarabaeidae) in forest fragments in Santa Maria, Rio Grande do Sul, Brazil. Anais da Academia Brasileira de Ciências 85 (2): 679-697.

SIMMONS, L.W. \& RIDSDILL-SMITH, T.J. 2011. Reproductive competition and its impact on the evolution and ecology of dung beetles, pp. 1-20. In: SIMMONS, L.W. \& RIDSDILL-SMITH, T.J. (eds.). Ecology and evolution of dung beetles. Oxford, Blackwell Publishing. $347 \mathrm{p}$.
SONEgo, R.S.; BACKeS, A. \& SOUZA, A.F. 2007. Descrição de uma estrutura de Floresta Ombrófila Mista, RS, Brasil, utilizando estimadores não-paramétricos de riqueza e rarefação de amostras. Acta Botanica Brasilica 21 (4): 943-955.

SPECTOR, S. 2006. Scarabaeine dung beetles (Coleoptera: Scarabaeidae: Scarabaeinae): an invertebrate focal taxon for biodiversity research and conservation. The Coleopterists Bulletin 5: 71-83.

TikAsingh, E.S. \& LAURENT, E. 1981. Use of ovitraps in monitoring Haemagogus equinus populations. Mosquito News 41: 677-680.

VAZ-DE-MeLLO, F.Z.; EdMONDS, W.D.; OCAMPO, F. \& SCHOOLMEESTERS, P. 2011. A multilingual key to the genera and subgenera of the subfamily Scarabaeinae of the New World (Coleoptera: Scarabaeidae). Zootaxa 2854: 1-73.

Viegas, G.; Stenert, C.; SCHUlz, U.H. \& Maltchik, L. 2014. Dung beetle communities as biological indicators of riparian forest widths in southern Brazil. Ecological Indicators 36: 703-710.
Recebido: 05/11/2014

Revisado: 01/09/2015

Aceito: 15/09/2015 